\title{
SUBSIDIARY CLASSIFICATION OF GOODS UNDER ETHIOPIAN PROPERTY LAW: A COMMENTARY
}

\author{
Muradu Abdo*
}

\section{Introduction}

The Civil Code of Ethiopia (the Code) classifies goods into corporeals and incorporeals ${ }^{1}$. Corporeal goods, in turn, are divided into movables and immovables $^{2}$. The classification of corporeal goods into movables and immovables in the Code can appropriately be termed as the primary classification of goods. Numerous other classifications complement such primary classification of corporeal goods. These other classification of things can collectively be termed as subsidiary (complementary or secondary) classification of goods. The subsidiary classification of things includes corporeals and incorporeals, consumable and non-consumable, fungible and non-fungible, divisible and indivisible, principals and fruits, things in public domain and private domain, collective and personal assets, and ordinary and special movables. ${ }^{3}$

There are numerous factors that set the primary classification of goods under the Code apart from the subsidiary classification of things. First, the division of corporeal goods into movables and immovables permeates the entire pri-

\footnotetext{
${ }^{*}$ LL.B, LL.M; Lecturer-in-Law (Faculty of Law, Addis Ababa University)

${ }^{1}$ The title of Book III of the Code which is entitled "Goods" as well as the reading of Article 1126 of the same implies that the subject matter of property rights under the Code is goods. In this Commentary, I have employed the terms "things", "corporeal goods," "property" and "goods" interchangeably to mean the resources, tangible or intangible, over which property rights may be established. The Code uses these words rather inconsistently.

${ }^{2}$ The English version of Article 1126 of the Code classifies "all goods" into movable and immovable. The reading of the Amharic and French versions of Article 1126 of the Code shows that what is divided into movable and immovable under this provision is not just goods but corporeal goods. See Billilegn Mandefro, Revised Unofficial Translation of Arts. 1126-1500, 1647-1674 of Book III,

Civil Code (1960) From the French Original Draft, (AAU, Law Library, Unpublished) (1973-1975).

${ }^{3}$ There are other classifications with secondary importance under Ethiopian law. See Article 665/3 of the Criminal Code of Ethiopia (2005) which divides movable things in terms of value into those things with very small economic value" and those things with higher economic value. See also Article $669 / 1$ and Article $681 / 2$ of the same which deal with "sacred or religious objects, or objects of scientific, artistic or historical value...' See also Article 1094 of the Code which divides things with sentimental value (family objects) and those things without sentimental value. Discussions about intrinsic and accessories and elements as regulated in Articles 1131-1134, and Articles $1135-1139$ of the Code are not made here since they are an aspect of the primary division of corporeal goods under the Code.
} 
vate and public law of Ethiopia generally and the Code particularly. ${ }^{4}$ Second, the majority of the provisions of Book III of the Code are devoted to the regulation of the various aspects of movables and immovables goods. ${ }^{5}$ Unlike the primary division of corporeal goods, the subsidiary division does not have a pedigree in the history of the civil law tradition to which Book III of the Code is traceable. Further, the primary classification of goods, which is based mainly on a lay notion of mobility, is considered to be fundamental in the structure of the Code. The primary classification implies the significance accorded to immovable property in Ethiopia, be it in the past, present and in the foreseeable future. Finally, the division of things into movable and immovable is closer to common sense; such division is also thought to be understandable to non-lawyers. Hence, when it comes to classification, the Code is designed in such a way that the primary division would have farreaching consequences while the subsidiary divisions would have comparatively limited effects.

The above distinctions do not however imply that the subsidiary classification of things is trivial which does not require any treatment in property law. Nor do such distinctions between the primary and subsidiary classification of goods suggest that property law literature should offer a scant attention to the subsidiary classification. The differences between the two groups of goods do simply imply the relatively greater importance given to immovable things in the Ethiopian property law.

The subsidiary classification of things in the property law of Ethiopia is numerous and quite useful to fully grasp the basics of property law. The subsidiary classification of goods is valuable in order to settle some disputes. As will be shown later on, there are several issues of acquisition, transfer and extinction of ownership in respect of things which are not addressed in the Code by the primary classification. The subsidiary classification steps in to fill such gaps in the Code. Without the complementary role assigned to the subsidiary classification, many issues of property law would be left unregulated in the Code. In addition, the uniqueness of certain goods (e.g., those in the public domain of the state) warrants specially designed rules. The subsidiary classification can subsume the primary classification; and as such it is possible to craft property law of a given country without even making men-

\footnotetext{
${ }^{4}$ The law of movables and immovables affects the majority of the notions included in Book III of the Code, contract law, agency law, law of persons, mortgage, antichresis, civil procedure, criminal law and commercial law, etc.

${ }^{5}$ For example, the following articles in the

Code do exclusively apply to immovable property: Arts. 1207-1256 (special rules applicable to immovable property and use and ownership of water), Arts 1359-1385 (servitude), Arts 1460-1488 (expropriation) and Arts 1553-1646 (registration of immovable property).
} 
tion of the primary classification of things. The use of division of corporeal goods into movables and immovables is not thus something that cannot be dispensed with.

Property law literature has given little coverage to the treatment of subsidiary classification of things. Moreover, the legal rules dealing with subsidiary classification of goods are scattered over the various sections of the Code and other laws, which make a comprehensive treatment of such rules a task difficult to accomplish. Apart from their sparse distribution, many of the rules on subsidiary classification of things are incorporated in the Code in a manner not easy to discern. Such arrangement of and approach to the rules pertaining to subsidiary division of goods in the pertinent legal texts perhaps makes them go unnoticed. ${ }^{6}$

This Commentary considers the nature, criterion, significance and legal effects of the subsidiary classifications of things under Ethiopian property law. This explanatory endeavor will hopefully make rules relating to the subsidiary classification of things more explicit, accessible and hence less obscure to a student of property law. This Commentary relies on analysis of the pertinent legal provisions of the Code and the Commercial Code of Ethiopia as well as on comparative law.

\section{Corporeals and incorporeals}

The division of goods into corporeals and incorporeals is one of the multitudes of subsidiary classifications recognized in the property law of Ethiopia. A corporeal thing is any product a human person can perceive whereas an incorporeal thing is any product that humans cannot perceive, but which has economic value. ${ }^{7}$ Incorporeal things are rights of property that can only be claimed or enforced by legal action and not by taking physical possession such as bank accounts, shares, trademarks, trade secrets and copyrights. The critical test for classifying things into corporeal and incorporeal products is human perception.

\footnotetext{
${ }^{6}$ Recently, the writer has gone through property law course outlines of five different law schools in Ethiopia in order to see if issues related to subsidiary classification of things are covered in property law classes in the country. Assuming that what is taught is what is included in a course outline, the result is that such course outlines have not included the various types of secondary classifications with the exception of the

classification of things into private domain and public domain of the state, which appears to be included because it is included in the Code at a paragraph level.

${ }^{7}$ See the Constitution of the Federal Democratic Republic of Ethiopia, Article 40/2, Proc. No. 1. 1995, Fed. Neg. Gaz., Year 1. No.1. This sub-article defines private property in terms of tangible and intangible product with value.
} 
Roman law classified objects, i.e., all things whether or not appropriable, into res corporeals and res incorporeals. To the Romans res corporeals meant physical objects and included the right of ownership, which could be felt by the senses. To them res incorporeals meant, on the other hand, objects without physical existence but having pecuniary value such as inheritance, obligations and all real rights with the exception of ownership, ${ }^{8}$ which curiously was regarded as objects having existence in space. The Romans introduced this dichotomy since they thought that possession and obtaining ownership was thought to be possible in respect of physical objects only. ${ }^{9}$

Article 461 of the Louisiana Civil Code divides things into corporeal and incorporeal. Corporeal things, under this Code, are those objects which are made manifest to the senses, which we may touch or taste, which have body, whether animate or inanimate. ${ }^{10}$ In the same Code, incorporeal things are objects which are not manifest to the senses, and which are conceived only by the understanding such as inheritance, servitudes and obligations. ${ }^{11}$ The French Civil Code of 1804 does not provide for the division of things into corporeals and incorporeals. But authorities there have arrived at a slightly different version of this classification by way of inference from the joint reading of several articles of the French Civil Code, i.e., the division of estates (biens) into things (choses, biens coporeals) and rights (droits, biens incorporeal). ${ }^{12}$ Such classification has importance in relation to the rule under Article 2279 of the French Code that states that possession is equivalent to ownership in relation to movables as such rule does apply only to corporeal movables. $^{13}$

Under the German Civil Code of 1900, property interests such as ownership, usufruct and right of recovery may be established only over corporeal things. The law of property in that country does not govern incorporeal objects, which do have economic value and are the subject matter of appropriation. ${ }^{14}$

In the Ethiopian property law, the distinction between corporeal and incorporeal goods is important because there are numerous articles applicable to cor-

\footnotetext{
${ }^{8}$ Roman jurists, conceived ownership not as an intangible thing but as a tangible thing because they were unable to distinguish the right established on an object from the object over which the right was constituted. See Marcel Planiol, Treatise on the Civil Law, Vol 1., Part II $12^{\text {th }}$ Ed. 1939 (Trans by Louisiana Law Institute) at 282.

subject of possession, and thus the formulation of the concept of quasi-possession in relation to such rights. Id., at 341 .

10 http://www.findlaw.com/11stategov/la/ civilcode.html (accessed January 10, 2008). ${ }^{11} \mathrm{Id}$.

${ }^{12}$ See Marcel Planiol, Supra Note 8 at 282.

${ }^{9}$ Later in the course of the evolution of prop- ${ }^{13} \mathrm{Id}$. erty law, it was appreciated that real rights ${ }^{14}$ See Athanassios N. Yiannopoulos, Infra such as usufruct and servitude could be the Note 29 at 775 .
} 
poreal goods alone; ${ }^{15}$ there are also provisions in the Code whose application is limited to incorporeal things. ${ }^{16}$ The relevance of the dichotomy also lies in the message of Article 1126 of the Code. The governing version of this article classifies corporeal goods into immovable and movable. In addition, division of things on the basis of corporeality is implicitly recognized in, for example, Article 1128 and Articles 1347-1358 of the Code. One can also gather the division of goods into corporeals and incorporeals from the title of Book III of the Code by way of inference. The division under consideration is also enshrined in the FDRE Constitution. ${ }^{17}$

For the purposes of mode of acquisition and transfer of property rights, the Code equates incorporeal goods with those whose existence can be ascertained by the senses. This division is of some importance in the law of possession; in the case of incorporeal goods, the law of possession comes up with what we call quasi-possession since intangible things cannot be physically controlled in the sense of material assets. The possession of incorporeal things is expressed via the continued enjoyment thereof or by defending the right when the occasion calls for it. In the context of the law of usufruct, the beneficiary cannot make physical use of intangible things; her right is limited only to the enjoyment of the fruits of such subject matter.

For instance, a usufructuary or a copyright of trademarks or of a trade secret or of a share in a business association or of a credit or generally of an incorporeal thing may only reap the fruits thereof. It is not possible for such usufructuary to think of the other right (e.g., the right to physical control and use), which she would enjoy, if her usufruct is constituted over a nonconsumable thing, say, for instance, a car. The law of loan envisages a contract between a lender and a borrower in respect of corporeal goods for the latter is entitled under such contract to have physical control of the thing covered in the loan. The notion of license is introduced in connection with intangible things. What accrues to the licensee under contract of license is the right to collect fruits arising out of the subject matter of such contract. At the end of the usufruct, loan and license, the usufructuary, loanee and licensee are required to return the documents that symbolize the existence of the incorporeal thing they have been enjoying in the course of the contract. These persons are not supposed to restitute any thing else to the owner.

The law of movables and immovables (the primary classification of things) does not address the rights of the usufrucutuary, loanee and licensee on in-

\footnotetext{
${ }^{15}$ See Arts 1325-1346 of the Code which are ${ }^{16}$ See Arts 1347-1352 of the Code. exclusively applicable to things having cor- ${ }^{17}$ See the FDRE Constitution, Supra Note \begin{tabular}{l|l} 
pus. & No. 7.
\end{tabular}
} 
corporeal goods. This is because the primary classification is intended, in the main, to focus upon tangible things; the terms movable and immovable normally denote physical things. These terms might imply intangible things only by invoking legal fiction. To the extent that the subsidiary classification under consideration deals with the entitlements of the parties to contract of usufruct, of loan and of license, it discharges its complementary role in the Code.

As mentioned above, under Ethiopian law, not all corporeal goods are the subject matter of property rights. Property rights can be established on some corporeal goods while it is not possible to create such rights on some other corporeal goods. Corporeal goods are the potential seats of property rights only if they can be appropriable. Besides, not all incorporeal goods are the subject of property law. Only those incorporeal things which are expressly designated by law as the objects of property rights can be regarded as such. For example, Articles 1128, 1309, 1310 and 1347 of the Code can be taken as some of such designations. Certain incorporeal things fall within the domain of contract or tort law. A person's claim against a wrongdoer, or a claim of specific performance should clearly be put beyond the domain of property law because such actions are not directed against a person in respect of a thing. ${ }^{18}$

\section{Consumable and non-consumable things}

The central test for the classification of things into consumable and nonconsumable product is consumability. Intention (animus) alone does not make a thing a consumable or non-consumable. ${ }^{19}$ Consumability is rather ascertained by reference to an objective criterion (consumption or alienation) and the prevailing notion in the pertinent trade. ${ }^{20} \mathrm{~A}$ consumable thing is a movable thing, which is used up when first used or subjected to transaction. One cannot use the same consumable thing again and again. In the case of currency, for instance, if one has a Ten Birr note and if she wants to use it, she would inevitably put the note into circulation not to find the same Ten Birr note again. Or, if one orders a meal in a restaurant, she will finish off her meal the moment she eats it all. She cannot keep on eating the same meal all the time. A non-consumable thing is a product one can use for a prolonged period of time. One does not finish off a non-consumable thing the moment

\footnotetext{
${ }^{18}$ See Marcel Planiol, Supra Note 8 at 267270.

${ }^{19}$ Stretching party autonomy to give them a free hand to distort concepts based on facts and perhaps for apparently no good reasons flies in the eye of logic and common sense.

${ }^{20}$ Under Art. 1713 of the Code in the absence of a clear term in a given contract, the usage of the pertinent business community may be useful to determine whether or not some goods shall be taken as consumables.
} 
she uses it. One can use her house or ploughshare or table many times. Repeated use over a relatively longer period of time characterizes nonconsumable things.

Article 1327 of the Code attaches importance to the division in question, and the provision does not require a beneficiary of a usufruct to restitute the object given in usufruct in the case of consumables. The usufructuary of consumables is entitled to get ownership over the object the moment the usufruct is validly created and transfer procedures are finalized. ${ }^{21}$ The usufructuary of consumable things is, however, under the obligation to pay the value of such things calculated at the time the usufruct was created. ${ }^{22}$ In addition to such remedies, the possibility of returning things of comparable quantity and quality (to the bare owner) upon the extinction of the usufruct, is available even if such option is not preferred under Ethiopian law. A bare owner who has subjected her consumable things to usufruct is thus entitled to certain special protections. On the other hand, a beneficiary of usufruct over a nonconsumable is obliged to properly manage, in the course of the usufruct, and restitute the object when the duration of the right expires because the ownership of the thing lies in the bare owner.

The application of the loan for use provisions ${ }^{23}$ of the Code is possible in relation to consumable things and so are those articles of the Code dealing with letting and hiring. ${ }^{24}$ It appears that a finder of consumable things, especially when they are perishable things, is mandated by law to sell them out at a public auction and keep the proceeds thereof to the owner. ${ }^{25}$ A possessor in bad faith cannot be required to restitute the very consumable thing she purchased from a person without authority assuming that she has consumed them up the time of recovery by the true owner. Further, a possessor in good faith of some types of consumable things such as stolen currency and bearer instruments cannot be required to restitute them to the true owner. ${ }^{26}$

\footnotetext{
${ }^{21}$ Art. 1324/2 entitles a usufructuary to require at any time, advisably prior to the commencement of the usufruct, sureties where the usufruct extends to consumable goods. Here the term 'sureties' seems to exclude real security if the usufruct is established gratuitously. If the usufruct is created for consideration absent a contrary term in the contract the usufructuary will be required to provide personal guarantee. The Amharic version of sub-article 3 of this article entitles the bare owner to terminate

the usufruct over consumable things if the beneficiary is unable to furnish surety within a reasonable period of time or where she makes unlawful use of the thing; but in relation to non-consumable things, such things may be vested in a curatory.

${ }^{22}$ See Art. 1327/2.

${ }^{23}$ See Arts. 2767-2778.

${ }^{24}$ See Arts. 2727-2766.

${ }^{25}$ See Art. 1156

${ }^{26}$ See Art. 1167
} 
The law of consumables fills the lacunae present in the principal classification. In the case of the primary classification, transfer of ownership does not take place in the absence of cause implying transfer of ownership. But in the case of the law of consumable things, transfer of ownership inevitably takes place if the consumable thing is delivered even if the parties have intended to create usufruct or loan. The inevitability of such transfer arises out of the nature of the things involved, i.e., they cannot be of some use without being used up or alienated. If usufruct is established on a movable thing, the usufructuary is normally required to restitute the very thing she gets in the form of usufruct to the bare owner upon the termination of such usufruct; but the usufructuary of a consumable thing is not expected to make restitution of the thing given to her in the form of usufruct. Under the primary classification, a true owner is entitled to recover her thing from the possessor in bad faith, which is not possible in the case of the law of consumables if the possessor in bad faith uses such thing up. In relation to the issue of whether or not stolen currency and security bearer can be acquired via possession in good faith, the law of movables and immovables (the principal classification) leaves a gap covered by the law of consumables.

\section{Fungible and non-fungible things}

"Two or more things are fungible vis-à-vis each other if they belong to the same genre of things and if, by virtue of their physical characteristics or the intention of those who deal with them, they are interchangeable or substitutable one for the other in view of the end for which they will be used."27 The key test for the division of things into fungible and non-fungible is interchangeability. A fungible thing is normally a movable that is capable of interchange. Liquid and flour are fungibles. Normally, fungibles occur in trade in terms of number, weight or measure. One can exchange the same quantity of white (magna) teff with the same quantity of another white (magna) teff. Likewise, an Ethiopian Ten Birr note can be exchanged with another Ethiopian Ten Birr note. One can do the same in connection with the same quality and quantity of butter.

The possibility of replacement of one thing by another is not the only test of fungiblity. Parties, it may be argued, may declare a non-fungible thing to be a fungible thing or vice versa; the law may designate a thing to be a fungible thing. ${ }^{28}$ So there are four ways for a thing to become a fungible thing: its na-

\footnotetext{
${ }^{27}$ See A. Precis, "The Classification of Things”, htpp://faculty.law.isu.edu/jrtrahan/ class.doc (accessed on January 10, 2008)

${ }^{28}$ On the issue of basis of classification, Demolombe, as quoted in Yiannopoulos, says

the will of parties matters. Other jurists do argue other wise: while intention may be pertinent, a thing should be open to interchangeability in its natural state; the intention of the parties alone cannot... (cont.)
} 
ture of replaceability, party decision, the law, and notions prevailing in trade. $^{29}$

A non-fungible thing is an object that is incapable of interchange. Unless one makes some sort of arrangements, it is not easy to have interchange between, say, a plot of land and a house, both being non-fungible.

There are instances of making use of this division in the Code in the fields of property, contracts, successions and civil procedure. The law of fungibles does help one to determine as to who shall be an owner of a thing in the case of merger. Article 1183/1 of the Code is one instance where two or more fungible things owned by several persons are intermingled and could not be separated, or could be separated with excessive cost, the result of the mixture is joint property, prorate, of such persons. The possession and thus ownership of fungible things is transferred from a transferor to a transferee when, in addition to the conclusion of a juridical act, the seller "individualizes the thing (picks it out) or weighs, counts or measures out the required quantity of thing from her stock of things of the same kind" 30 and makes a declaration to that effect. The use of the terms "a particular thing" and "a specific chattel" in the pertinent provisions of the Code suggest that only non-fungible things may be the subject matter of preemption, promise of sale and right of recovery. ${ }^{31}$

The other instance is found in contract law, which states the quality of the thing that a debtor must deliver to her creditor. Art. $1747^{32}$ of the Code provides that where a contract relating to fungible things is silent about the quality of the fungible things due to the creditor, the debtor may opt to deliver an average quality of a thing, which conforms to the generic description of that fungible. In the case of non-fungible things, i.e., in case of specific (determinate) things, the creditor may, under some conditions, require the debtor to deliver the thing agreed or pay her monetary compensation for the subject matter of the contract cannot be replaced by another thing. ${ }^{33} \mathrm{~A}$ creditor may not invoke specific performance with regard to consumable things.

\footnotetext{
${ }^{28}$ (cont.) convert a non-fungible thing (e.g. a tract of land) into a fungible thing. See A.N. Yiannopoulos, Infra note 29 at 779.

which are consumable without being fungible (e.g. wine of a particular vintage).

${ }^{30}$ See Precis, Supra Note No 27. See also

${ }^{29}$ A.N. Yiannopoulos, 'Introduction to the Law of Things: Louisiana and Comparative Law,'22 L.L. R. (1961-1962) at 778. One may inquire into the difference between consumable and fungible things. Things which are fungible are also consumable. However, there are things which are fungible without being consumable (e.g. videocassettes of the same record) and things

Article 1145/1 of the Code.

${ }^{31}$ See Articles 1386 and 1411/1 of the Code, marking the words "...a particular thing..." and “...specific chattel...”, respectively.

${ }^{32}$ The application of Art. 1778 of the Code also hinges on the distinction between fungibles and non-fungibles. So is the application of Article 1145/1 of the same.

${ }^{33}$ See Articles 1745 and 1747.
} 
The law of fungibles has importance in the law of successions ${ }^{34}$ and civil procedure. $^{35}$ The use of the law of movables and immovables (the primary classification) alone would not enable one to handle the above issues. Thus, the concept of fungibles is embodied in the Code as a complementary tool.

\section{Divisible and indivisible things}

Divisible things can be split into several same units which can be assigned for individual ownership while that cannot be done in relation to indivisible things. Divisibility relates to the issue of whether or not physical apportionment of a certain physical thing, be it a movable or immovable, can or should be accomplished; if physical division can be attained, if that is economically sensible.

Under Roman law, things were divisible if they could be divided into several parts of the same kind as the whole without thereby suffering diminution in value. ${ }^{36}$ Article 1340 of the Civil Code of Louisiana states that a thing is indivisible if the consequence of dividing it would be a diminution of its value, or loss or inconvenience to one of the owners. Article 752 of the German Civil Code envisages the possibility of partition of things in kind in relation to those things which, without diminution in value, can be divided in equal parts corresponding to the shares of the co-owners. "A thing is indivisible if it cannot be physically divided into discrete parts or though it can be so divided, the parts cannot be used for the same purposes as the undivided thing, the parts are not of the same nature, the parts are not of the same value, or the aggregate value of the parts is significantly less than the value of the undivided thing., 37

The Code and the Revised Family Code $^{38}$ recognize the classification of immovable things into those, which are subject to division and those, which are not. In both Codes, the recognition of divisible and indivisible things is made in the context of co-ownership. Under Art. 1272/2 of the Code, a court to which a request for termination of joint ownership in respect of an immovable is made is expected to make order for sale instead of division where it finds such property to be indivisible either because physical individualization ${ }^{39}$ would be contrary to the nature of or purpose of the immovable or

\footnotetext{
${ }^{34}$ See Art. 1047 .

${ }^{35}$ See Arts. 225 and 226/3\& 4 of the Civil Procedure Code of Ethiopia (1965).

${ }^{36}$ Yiannopoulos, Supra note 29 at 780.

${ }^{37}$ See_Supra note 27.

${ }^{38}$ Reference here is made to the Revised Family Code, Proc. No. 213, 2000, Year $6^{\text {th }}$ Extraordinary Issue 1.

39 In both cases of matrimonial property upon
the dissolution of marriage and ordinary
joint ownership, the law gives the ex-
spouses and the joint owners the right to
insist on the physical partition, equally in
the case of the former and pro rata in the
case of the latter. See Art. 91 of the Revised
Family Code and Art. $1272 / 1$ of the Code.

${ }^{39}$ In both cases of matrimonial property upon the dissolution of marriage and ordinary joint ownership, the law gives the exspouses and the joint owners the right to the case of the former and pro rata in the Family Code and Art. 1272/1 of the Code.
} 
would reduce its economic value or seriously impair the making use of it. Under Article 1276 of the same Code, "joint ownership may be perpetual where...division thereof is impossible or would be unreasonable.” In the context of jointly owned movable thing, the Code, under Art. 1271/1, appears to be silent about the possibility of termination through division; such Article simply envisages sale by auction.

The possibility or desirability or feasibility of division in kind of a jointly owned movable cannot be ruled out. The Code itself, under Art.1264 envisages this when it stipulates that "each joint owner may at any time apply for the partition of” fruits of a thing jointly owned. Thus, certain jointly owned movables can be partitioned in kind (e.g. some meters of cloth or a certain quantity of maize). The Revised Family Code also signifies the possibility of dividing movable things because it simply says 'property. ${ }^{40}$ Art. 92/1 of the Revised Family Code provides that "if there is a certain property which is difficult or impossible to be divided..., such property shall be sold...”

Read together, provisions of the Code and the Revised Family Code described above imply criteria to determine whether or not a given property is open to partition in kind namely: desirability or economic feasibility or practical difficulty or impossibility. It may be undesirable to partition a jointly owned thing for which the co-owners have developed sentimental attachment. Undesirability of phyiscalization of marital property also exits; in fact, it may even be illegal for spouses to go for division of common property before their marriage is dissolved.

The issue of economic non-feasibility arises when the economic value of the units assigned to an ex-joint owner is exceedingly less than the economic value of the share in the thing before the division. Such non-feasibility should equally be said to exist when the size of the unit given to each joint owner or some of them is manifestly useless. The issue of difficulty or impossibility means that the thing, after the division, cannot serve its previous purpose or cannot maintain its existence. For example, a car is a composite thing and division of a car would basically means disassembling it and breaking it into spare parts. It is not possible to divide a plot of land on which a condominium is built during the life time of such condo. ${ }^{41}$ Nor are parts of a condominium intended for common enjoyment open to division in the course of the joint ownership of such building. A party wall cannot be partitioned. ${ }^{42}$

\footnotetext{
${ }^{40}$ See Art. 92/1 of the Revised Family Code

${ }^{41}$ See the Condominium Proc., Article 2/1, No 370, 2003

${ }^{42}$ Art. 1201/1 defines party wall as opposed

to private wall as `a wall or fence separating two parcels of land, ' which may be argued by virtue of contextual reading to include buildings or parts thereof.
} 
The consequence of the dichotomy of things into divisible and indivisible becomes clear when one asks the question: should the jointly owned thing be sold at public auction or divided if one of the joint owners opts to bring such ownership to an end? If the thing is divisible, then the solution adopted is physical partition of the thing jointly owned and apportionment of the resulting units to each joint owner according to her share. In effect, each co-owner goes away with a unit of the thing co-owned. In so doing, the share of each co-owner is localized in some material portion of the thing previously coowned, which might lead to the extinction of co-ownership. If it is not possible to divide a co-owned thing then follows public auction or private sale followed by division of the proceeds thereof among joint owners pro rata, which is called licitation. ${ }^{43}$ If the time for division or sale of the thing is not appropriate, it can be postponed for a certain period of time. ${ }^{44}$

The law of indivisible things is useful to remove one of the deficiencies in the law of movables and immovables. The straightforward application of the latter division of things does not offer a solution to the problem of bringing co-ownership to an end in the case of indivisible things.

\section{Principals and fruits}

The concept of fruits is useful in the application of some of the rules regarding acquisition of ownership (e.g. via possession in good faith ${ }^{45}$ and acces$\operatorname{sion}^{46}$ ), joint ownership, ${ }^{47}$ usufruct $^{48}$ and common property including per-

\footnotetext{
${ }^{43}$ Supra Note 27

${ }^{44}$ See Arts. $1271 / 2$ and 1273 of the Code. In the case of movables, the court, upon the application of one of the joint owners, has the power to postpone the sale or division up to six months while, in the case of immovables, the court can postpone it for a maximum of two years. The request for postponement may be based on anticipated rise in the price in the thing or the thing is under construction or some issues of claim by a third party are anticipated. In the mean time, where necessary (e.g. the co-owners are in serious discord), the court may appoint a person who administers the property.

${ }^{45}$ See Arts. $1161-1167$ of the Code. Under this provisions, though nothing is stated about the fate of fruits obtained out of a thing delivered to a person in good (in the case of stolen things) or in bad faith, it ap-
}

pears sound to argue that the person in either case should return not only the principal but also the fruits which she has collected in the course of the possession of the thing. This is precisely because she is not the owner of the thing in her possession and absent a contrary stipulation she who owns the principal owns the fruits thereof.

${ }^{46}$ See Arts.1171-1283.

${ }^{47}$ See Art. 1264 of the Code.

${ }^{48}$ See, for examples of, Arts. 1309, 1311, 1328 and 1331 of the Code. In relation to corporeal goods, a usufructuary has two rights: the right to use such thing given in usufruct and be the owner of the fruits thereof whereas in the case of incorporeal things (e.g. usufruct over trade secrets), the nature of the object of the usufruct dictates only the enjoyment of fruits. 
sonal property of one of the spouses ${ }^{49}$ both in the course of marriage and after its dissolution. These cases trigger the question as to who, and as of when, shall be the owner of the increments (fruits) of the main thing (which is subject to joint ownership, usufruct, pledge and marital property). The primary division of corporeal goods into movables and immovables lacks an answer to this question. Thus, the division under consideration here is set out to remedy this deficiency in the law of movables and immovables as enshrined in the Code.

According to several provisions of the Code, which need to be read together, 'fruits ${ }^{, 50}$ are increases of a thing in conformity with its purpose without diminution of the principal thing. Fruits are all that a thing produces at periodical interval without diminution of its own substance. ${ }^{51}$ If fruits are not obtained at a regular interval or produced using the substance of the main thing, they are called products, which mark the distinction between fruits and products. The term 'regular interval' means production of increases yearly or at a shorter interval. ${ }^{52}$

Fruits are further classified into natural fruits and artificial fruits. Natural fruits are those fruits, which are the periodic increments of animals and plants. ${ }^{53}$ Artificial fruits are classified into civil and industrial fruits. Civil fruits are fruits, which are entitlements either by virtue of law or agreement; civil fruits do not come out of the body of the principal thing. ${ }^{54}$ Such is the case with interests on sums of money or profits from a business association and rents obtained out of a non-consumable thing. Fruits that may be obtained by cultivation or workings on the soil are called industrial fruits (e.g., trees and crops) ${ }^{55}$.

\footnotetext{
${ }^{49}$ See Art. 62/1 of the Revised Family Code which declares that all fruits regardless of their nature obtained out of both personal and common property shall be taken as matrimonial property.

${ }^{50}$ See Arts. 1170, 1171 and 1333.

${ }^{51}$ The French Civil Code and Louisiana Civil Code do not explicitly define the notion of fruits; both rather come up with the classification fruits as fruits of nature, fruits of civil transaction and fruits of industry. In the two jurisdictions, writers and courts have inferred from their respective civil codes a definition of fruits which is things produced periodically by a principal thing without diminution of its importance. See A. N.

Yiannopoulos, Supra Note 29 at 785 . The German Civil Code, on the other hand, under Article 99, states that:" fruits of a thing are the products of the thing and such other profits as are obtained from the thing according to its destination. Fruits of a right are the revenues which the right yields according to its destination, particularly where one has a right to obtain parts of a thing or a right to yields by reasons of a legal relation."

${ }^{52}$ This is an inference from Article 1333 (a).

${ }^{53}$ Marcel Planiol, Supra Note 8 644-650

${ }^{54} \mathrm{Id}$.

${ }^{55} \mathrm{Id}$.
} 
Products are fruits that may be collected from a thing by adding something to the principal thing mainly in the form of labor and raw material, which consequently diminishes the substance of the principal thing. The Code assimilates products to fruits under some situations. The assimilation occurs where products (e.g. wood cuttings, quarries and minerals) are collected according to the usage, in conformity with the purposes of the principal thing as well as agreed upon working plan preferably prior to the commencement of the usufruct. $^{56}$ But it is not clear where the demarcation that separates the periodic and non- periodic products lies.

In terms of legal effects, natural and industrial fruits become property of the owner of the principal thing upon their separation from the latter. The general rule is that a person who owns the main thing also owns the fruits thereof based on Articles 1170 and 1171 of the Code. The ownership of fruits of the breeds is given to the owner of the mother should the owner of the father claim ownership. For example, the owner of a cow owns the calf without regard to who owns the bull. ${ }^{57}$ Joint owners of a thing are owners of the fruits or products of such thing proportionate to their share in the principal. ${ }^{58}$ Under Ethiopian family law, fruits of both personal and common property are taken as common property. ${ }^{59}$ In principle, an owner whose possession has been deprived by another person is entitled to claim the recovery not only of the main thing but also the fruits thereof precisely because the main thing belongs to the original owner.

The rule that she who owns the principal is the owner of the fruits thereof suffers from exceptions. A usufructuary, not a bare owner, is the owner of the fruits produced by the thing given in usufruct between the date of creation and date of extinction of such usufruct. ${ }^{60}$ In the course of lease, the lessor

\footnotetext{
56 The Code creates fiction under Article $1170 / 2$, which states that "periodical products of a thing and anything which may according to usage be derived from a thing in conformity with its purpose shall be deemed to be fruits. " In the context of usufruct, the Code prefers working plan to mere usage in assimilating products to fruits. See Articles 1333-1335 of the Code which envisage the right of the owner or the usufructuary to require the drawing up of plan of exploitation either by themselves or an expert failing agreement; the working plan can be modified under some situations at the request of either party.

57 http://www.britannica.com/eb/article-28554 (Accessed 16 February, 2006)

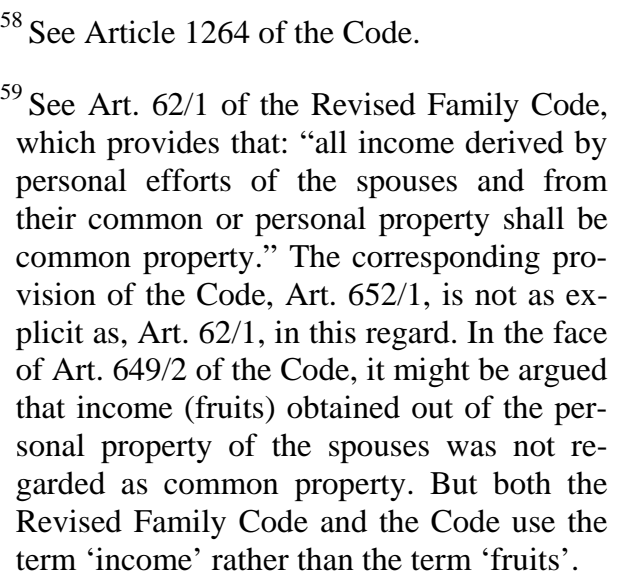
which provides that: "all income derived by personal efforts of the spouses and from their common or personal property shall be common property." The corresponding provision of the Code, Art. 652/1, is not as explicit as, Art. 62/1, in this regard. In the face of Art. 649/2 of the Code, it might be argued that income (fruits) obtained out of the personal property of the spouses was not regarded as common property. But both the Revised Family Code and the Code use the term 'income' rather than the term 'fruits'.

${ }^{60}$ See Art. 1328 cum Art. 1331 of the Code.
} 
cannot claim the ownership of the fruits out of the thing covered by the lease. In the case of unlawful enrichment, the person required to make restitution is given the right to retain the fruits of the property he has received. ${ }^{61}$ In the event of return of the absentee, the fruits of her property collected by her presumptive heirs or legatees are given the option to retain such fruits. ${ }^{62}$

\section{Things in the public and private domain of the state}

Every state, irrespective of the ideology it subscribes to, needs property in the sense of goods capable of appropriation. ${ }^{63}$ Of course, a state with a socialist ideology is expected to have a lot more property than a state with a capitalist ideology. Property under state control enables it to carry out its classical functions. ${ }^{64}$ The state uses its property to discharge its roles. ${ }^{65}$ Take roads, bridges and national museums. Generally every body has access to these resources. Ethiopian property law calls this type of resources property in the public domain of the state. As will be considered below, property in the public domain of the state is a piece of property owned by the state but accessible equally to every body. Things in public domain may be immovable or movable things. Members of a given local or national community profit from things in the public domain directly whereas property in the private domain of the state benefit the public indirectly. Things in the public domain may be under the control of private persons though usually such resources are put under the custody of public authorities. ${ }^{66}$

As the reader may have noticed, the preceding sections of this Commentary have explained goods regardless of the identity of the owner of such goods. In this section, what is examined is the nature, classification and the effects

\footnotetext{
${ }^{61}$ See Art. 2178/1.

${ }^{62}$ See Art. 171/2.

${ }^{63}$ The term 'property' is used under Arts 1444-1459 to refer to the objects of property rights, not to refer to property rights.

${ }^{64}$ These functions include the classic tasks such as defense, security and the administration of justice as well as the modern ones such as redistributive, allocative and stabilization functions.

${ }^{65}$ At present land and water including natural resources, in Ethiopia, are collectively owned. These resources are automatically taken as part of public domain things; they may or may not be the case. Public domain things are different from common things (e.g. the ocean) and public domain things
}

are not the same as collective things (such as land and water in Ethiopia today).

${ }^{66}$ There may be antiques (e.g. an old spear and shield) held by a private person. The public will have access to these cultural heritages in same way and the person in possession of such objects will have a limited ownership right. The heading of Section I of (Book III, Title IX, Chapter 1) the Code reads just "Public Domain", which implies that if the property should be dedicated to public use or public service, it is immaterial whether possession thereof lies in a private or public persons. Thus, all property owned by private persons does not necessarily belong to the private domain and all property owned by the public institutions does not fall within the ambit of its public domain. 
thereof of things under the custody of the state. What the lawmaker seeks to regulate under Articles 1444-1459 of the Code is a unique category of property both in terms of the manner in which the resources involved is sought to be used and the feature of the administrator of such property. This unique legal situation cannot properly be captured by the rules devoted to the principal classification of corporeal goods under the Code.

\subsection{The Basis of the classification}

The Digest, the principal Roman legal document, distinguished three kinds of state property, namely: (a) public property not open to private ownership or property serving public purpose; or (b) things which were destined to public use; and (c) property of the state or its political sub-divisions which was susceptible of private ownership and subject to the rules of civil law like any other property held by private persons. ${ }^{67}$ Hence, the Romans regarded those resources dedicated to public purpose or public use as property forming part of the public domain of the Roman state while some other resources held in the hands of the state but not so open to the public were taken as property forming part of the private domain of the state. Public use or dedication to public purpose was the distinguishing mark of property which formed part of the public domain of the state.

Article 1444 of the Code dissects property (goods) into two broad classes, namely property in the private domain and property in the state domain. The same article further divides the latter (property in the state domain) ${ }^{68}$ into private domain of the state and public domain of the state. The property so sub-classified might be held by political units at any level of the Ethiopian

${ }^{67}$ See A. N. Yiannopoulos, Infra Note 69 at 706.

${ }^{68}$ See A. N. Yiannopoulos, Infra, note 69 at 705. In Louisiana, state owned things are divided into three: (a) "things dedicated to public use; title to these things is vested in the state, but this title should be regulated by rules of public law rather than the Civil Code. The Code merely regulates only some incidents of the public use of such property. This is insusceptible of private ownership and thus exempt from seizure, prescription and alienation in general. (b) "Another category of things belonging to the public domain consists of the things such as streets, public walks, quays and public squares. These things, dedicated to public use and out of commerce, ordinarily belong to political sub-divisions of the state. And (c) property of the private (national) domains of the state is property susceptible of private ownership. Such property, though serving public purposes directly or indirectly, is not subject to public use. It is clearly alienable by the state, but, for reasons of policy, not subject to seizure and prescription against the state. To the private domain belongs also property of political subdivisions of the state which is not destined to public use. As in the case of similar property held by the state itself, such property is susceptible of private ownership and alienable but not exempt from prescription." See also Arts. 453 and 454 of the Louisiana Civil Code 
Government, federal and state, and regardless of the type of property, be it movable or immovable.

The basis of the division of state property into property in the private domain of the state and property in the public domain of the state is controversial. One view is that the criterion of the division must lie in whether a certain property belonging to the state is not susceptible of private ownership. According to this view, insusceptibility of private ownership is the criterion on the basis of which one categorizes certain goods into public domain of the state. ${ }^{69}$ This view triggers the question: are there things, which are absolutely insusceptible of private appropriation?

A second view states that the true reason for the dichotomy is dedication of a certain thing to the public service, not innate insusceptible of private ownership. ${ }^{70}$ To this latter view nothing on earth is inherently incapable of private appropriation. ${ }^{71}$ And the law makes the dedication. There are certain resources, tangible or other wise, which shall be regarded as things in the public domain of the state just by virtue of their dedication to the public use or purpose. It is to be noted that things in the public domain can be commercialized while they are in the hands or under the control of the public authorities, though to a very limited degree.

The Code adopts the second view. It is not any innate attribute of a thing which makes it qualify for the category of property in the public domain, but it is rather the needs of a given community as reflected in its laws or practices or policy that makes a given thing part of public domain of the state;. So virtually anything open to appropriation can fall within the scope of property in the public if so declared by a concerned community. The fact that a given property is inalienable or is not subject to prescription does not mean that it is inherently incapable of private appropriation but the inalienability or imprescriptibility may rather come out of dedication of such thing by law to the common good.

\footnotetext{
${ }^{69}$ See A.N. Yiannopoulos, “Common, Public, and Private Things in Louisiana: Civilian Tradition and Modern Practice,” 21 Louisiana Law Review (1960-1961) at 704.

${ }^{70}$ Ibid. Some tend to split this second view into distinct positions capitalizing on the terms `public use` and `public service.' See, for example, “...the essential characteristic of property within the public domain finds in dedication to public service. " As to the

third view, the essential characteristic of property within the public domain is dedication to public use."

${ }^{71}$ See A.N. Yiannopoulos Supra Note 69 at 17. This is based on the realistic consideration that, while all things are by their nature susceptible of ownership, consideration of public utility and convenience may require certain things to be withdrawn, entirely or in part, from the sphere of free private relations.
} 
The Code deals with property forming part of the public domain of the state without providing a clear-cut definition of the term. Instead, the Code gives us a guideline and some examples of property in the public domain. The basic guideline is whether a certain property is held by the state and whether or not that property is accessible to every body for use or destined to a public purpose.

Article 1445 (a) of the Code provides that a thing is regarded as falling in the public domain of the state if "it is directly placed or left at the disposal of the public." Article 1445 (b) of the same adopts another alternative criterion. ${ }^{72}$ According to this standard, there is a certain good, and there is a public service, ${ }^{73}$ and the former is destined to the use of the latter in order to promote its particular objective. The authorities in charge of the administration of things in the public domain may charge fees. These fees are merely considered as service charges and payment of service charge to access things in public domain of the state may not warrant one to say such property is in the private domain of the state. The obvious implication of Article 1445 of the Code is that all goods, movable or immovable, in the hands of the state that meet the requirement of this Article will fall within the ambit of public domain of the state. In other words, all things the state controls and which do not meet the test of Article 1445 fall within the private domain of the state.

It seems that test of public use or public service under Article 1445 of the Code applies to situations other than the ones explicitly mentioned as examples in Articles 1446-1447 and Article 1255 of the same. Article 1445 is a fall back provision. That is, there is a certain property belonging to the state and that property could not fall within the scope of Articles 1446-1447 and Article 1255; then, recourse should be made to the test set forth in Article 1445, i.e., public use (accessibility) or public purpose.

\footnotetext{
${ }^{72}$ A.N. Yiannopoulos Supra Note 69 at 771. Things under the possession of the state and dedicated to a public purpose differ from things dedicated to public use in that the public served by them is not public use. Like things dedicated to public use, these are susceptible of private ownership but only to the extent compatible with public purpose. In this category belong state-owned buildings housing governmental offices and educational and health institutions. Municipal buildings housing offices and institutions belong to the same category.
}

\footnotetext{
${ }^{73}$ See Arts. 3207-3243 of the Code. In particular, look at Art. 3207/1 which provides for the definition of public service as follows: an activity which a public community has decided to perform for the reason that it has deemed it to be necessary in the general interest and considered that private initiative was inadequate for carrying it out shall constitute a public service. On the authority of this stipulation, one may argue that the investment activities of some public enterprises in Ethiopia may be regarded as public service.
} 
Articles 1446-1447 and Article 1255 of the Code furnish examples of things that must fall within the public domain. As regards these illustrations, there would be no controversy for the Code requires one to categorize them automatically into the public domain. Under Articles 1446-1447 and Article 1255 , mention is made to antiques one finds in museums, roads, streets, canals, railways, seashores, port installations and lighthouses, churches, mosques, fortresses, waterways, lakes and underground accumulations of water fall within the public domain of the state. ${ }^{74}$ It is submitted that there are many kinds of property that may be designated as property in the public domain of the state. ${ }^{75}$ For instance, the period of protection of patent and copyrights is limited under Ethiopian law. Enjoyment of these rights is not for an indefinite period of time. After the lapse of a period determined by law, the public is free to use patented ${ }^{76}$ and copyrighted materials whose duration has lapsed. $^{77}$

\subsection{Legal effects}

The legal effect of the classification of property belonging to state or other administrative bodies into private domain and public domain is the application of different rules to each of them. There are three options in determining which rules shall apply to the regulation of property in the public domain of the state. Option one is to regulate objects in the public domain of the state exclusively on the basis of private property rules. For example, in the German Civil Code, "state property is in all cases private property; however, exercise of ownership rights is limited in the interest of public use and public purpose. The power of the state to regulate public use and public purpose is not regarded as an incident of ownership but as authority deriving from the sphere of public law properly belonging to the state."78

The second approach is to treat things dedicated to public use or public service entirely under public law; here private law will have nothing to say

\footnotetext{
${ }^{74}$ See also Art. 130 (a \&d) of the 1955 Revised Constitution of Ethiopia for additional list of things in the public domain of the state which was probably reflected in the Code.

${ }^{75}$ For the additional list of property included in the public domain of the state, see Research and Conservation of Cultural Heritage, Art. 2 (7\&8), Proc. 209, 2000, Fed. Neg. Gaz. Year 27 No 39. See also the Ethiopian National Archives and Library, Art. 2/20, Proc. 179, 1999, Fed. Neg.Gaz. ${ }^{76}$ See Inventions, Minor Inventions and Industrial Designs, Art. 16, Proc., No 123, 1995, Year $54^{\text {th }}$ No 25: A patented invention falls within the public domain, perhaps becomes a common thing, twenty years after the issuance of certificate of patent in favor of the owner.

${ }^{77}$ See Copyright and Neighboring Protection, Art. 20, Proc No 410, 2004, Year $10^{\text {th }}$ No 55. In broad terms, copyright expires fifty years after the death of the author.

${ }^{78}$ A.N. Yiannopoulos, Supra Note 69 at 771. Year 29 No 63.
} 
about things out of commerce. Article 714 of the French Civil Code appears to adhere to this pattern. Finally, the third approach is to govern public domain things partly under a civil code and partly under administrative law. According to Planiol, Civil codes should to some extent treat things in public domain for a couple of reasons: private property everywhere comes in contact with the public domain and that the general classification of things belong essentially to a civil code which should "contain the basic principles of law.",79

This hybrid system is the preferred approach under the Code. The mixed approach rests on the belief that both public law and private law should in different respects govern property forming part of the public domain of the state. Titles VI, VII and VIII of Book III of the Code govern property in the private domain of the state and property held by persons other than the state. In other words, Articles 1126-1443 of the Code govern state property in the private domain. Article 1444(2) provides that "property belonging to the state or other administrative bodies shall be subject to the provisions relating to property privately owned." The state owns property in its private domain same as property is owned by an individual or a company.

The consequence of this is that property forming part of the private domain of the state could be alienated (either freely or for consideration), acquired through possession in good faith, occupation, prescription and accession. However, if a certain property is categorized into the public domain of the state, Articles 1444-1459 of the Code shall govern it. These articles do not claim to treat every issue connected to things in the public domain; they simply provide one with skeleton. Articles 1454 and 1455 state that property which forms part of the public domain may not be alienated nor could it be acquired by possession in good faith ${ }^{80}$ or usucaption. ${ }^{81}$ The consequence of this is that state property in the public domain may not be alienated either freely or for consideration even by the state or its administrative units, which are merely regarded as custodians. Further, no one can acquire ownership over such property through possession in good faith or usucaption. Nor can one acquire property in the public domain through occupation (for they are already occupied) and accession.

\subsection{Possibility of limited marketability}

Property forming part of the public domain of the state is not absolutely put beyond commerce. The public authority, which is in charge of the manage-

\footnotetext{
${ }^{79}$ Marcel Planiol, Supra Note 8 at 814.

${ }^{81}$ These provisions should be read to put

${ }^{80}$ See Art. 1161-1167. things in the public domain beyond the reach of attachment as well as prescription.
} 
ment of things in public domain, has certain powers, which imply that things in public domain under the Code can be subjected to limited private relations. Things in public domain may be given in concession of permanent or temporary nature to private persons. Such concession, however, must not have the effect of altering the purpose of such property. ${ }^{82}$ For example, if there is a national museum and if it has artifact shops and restaurants the latter may be contracted out to private individuals.

Besides, the public authorities may authorize private persons to occupy such property and construct works on the same. ${ }^{83}$ A certain street may be given out in concession to a private company to put up advertisements and permit others to do so with payment. But, in the course of such contractual arrangement, the street will be open to vehicles and pedestrians. In order for an individual to occupy property in the public domain, there must be authorization which specifies whether the person is allowed to undertake construction. Moreover, the character of such construction as well as the time for which the authorization is granted and the fees chargeable ought to be expressly stated. $^{84}$

The public authority that gives the authorization or grants the concession is given the power to cancel the authorization or the concession if the private individual (beneficiary) fails to adhere to the conditions specified in the agreement. ${ }^{85}$ Pursuant to Article 1459 of the Code, the public authority is empowered to order the destruction of any work or the cessation of any activity by the beneficiary, which in fact impairs the very existence or the purpose of the property forming part of the public domain. The authority which is bestowed with the custody of public domain property should have the right, of course on behalf of the public, to bring possessory and petitory actions. ${ }^{86}$

\subsection{Enlargement of the public domain}

Article 1450 of the Code envisages two means through which public domain may increase or expand: ${ }^{87}$ expropriation and alignment. Expropriation relates to the taking away of rights in immovable property in return for advance payment of compensation for public purposes. ${ }^{88}$ The property taken through ex-

\footnotetext{
${ }^{82}$ See Art. 1456 of the Code.

${ }^{83}$ See Art. 1457 of the Code.

${ }^{84}$ See Art. 1457 (2\&3) of the Code.

${ }^{85}$ See Art. 1458 of the Code.

${ }^{86}$ This is simply inferred from Arts. 1148 1149 and 1206 of the Code that recognize the right of a holder to file possessory action against a usurper.

${ }^{87}$ In addition to these two avenues, the state
}

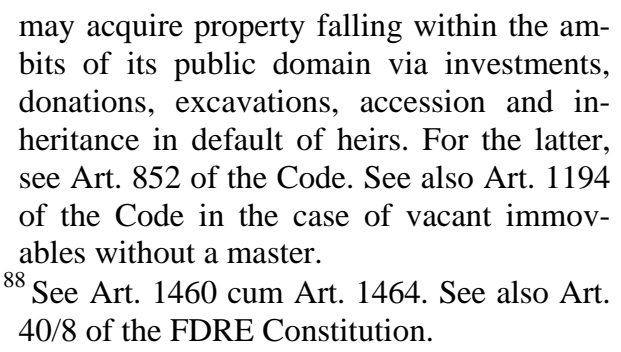
bits of its public domain via investments, donations, excavations, accession and inheritance in default of heirs. For the latter, see Art. 852 of the Code. See also Art. 1194 of the Code in the case of vacant immovables without a master.

${ }^{88}$ See Art. 1460 cum Art. 1464. See also Art. 40/8 of the FDRE Constitution. 
propriation may enter the public domain. ${ }^{89}$ Alignment proceeding, on the other hand, helps the competent authorities to widen narrow or straighten zigzag or lengthen short roads or streets ${ }^{90}$. Where the alignment proceeding reveals that certain un-built plot of land falls within the public highways, then, such plot of land will be automatically incorporated to such public ways. ${ }^{91}$ Alignment plans are particularly related to town planning.

\subsection{Shrinkage of the public domain}

There are three grounds on the basis of which things once in the public domain cease to be so and enter into the private domain with its apparent legal consequences. One such ground is declassification through declaration. According to Article 1454 of the Code, the pertinent public authority may alienate property forming part of the public domain after having declared it no longer part of the public domain. The second ground for withdrawal of things from public domain is non-use. If a thing in a public domain, for example, a street, is no longer in use, it may be open for private appropriation. If a fortress serves no longer its purpose, then it would fall within the private domain. The third factor is a natural cause. For instance, a building in the public domain may collapse as a result of earthquake or other natural disasters.

\section{Personal and collective things}

Written in the spirit of private ownership of the critical resources of the country, the Code could not envisage the division of things into personal and collective things. This subsidiary classification of things has been added to the property law of Ethiopia since 1975. The division in question is still of some relevance because the FDRE Constitution has maintained collective ownership of natural resources including land as the legacy of the Ethiopian revolution. This dichotomy of things helps us to identify things open to private ownership and those which are put beyond the reach of private ownership. This subsidiary classification is an attempt to link the wealth of an individual to her labor and to her material and spiritual needs.

\subsection{Nature and basis of the classification}

The term "personal things" is not used here to mean property owned by one of the spouses in the course of marriage ${ }^{92}$ nor is the term under consideration used to connote human faculties which may be the sources of immense

\footnotetext{
${ }^{89}$ This will be true to the extent expropriation $\mid{ }^{91}$ See Art. 1451 of the Code. is invoked to expand the public domain of the state.

${ }^{90}$ See Art. 1450.

${ }^{92}$ See Arts. 57-58 of the Revised Family Code.
} 
power and wealth. ${ }^{93}$ Rather, the term is employed as opposed to collective assets in the ideological sense. Personal things are resources owned by a physical person for her own survival, comfort, convenience and cultural needs as well as those persons living with her. ${ }^{94}$ Personal assets shall be linked to the person of the owner of such assets.

The term "personal asset" implies that the owner of such assets should not be allowed to accumulate property which would permit her to hire and exploit the labor of others. It also implies that the principal source of personal assets shall be the labor of the owner herself. The basis of the dichotomy of things into personal and collective seems to be an ideological preference. Personal things can be transferred via sale, donation, inheritance and attachment.

In order to ensure that the possessions of individuals do not grow into productive assets, mechanisms are devised such as limiting the size, the number and the magnitude of such property. And constant nationalization is employed as well. Property in personal ownership includes "a one-family house, a one-family apartment, household articles, clothing and motor vehicles, etc. The list of articles which may belong to a person varies according to her place within the social and economic stratification in her society."95

All resources other than those permitted to be owned by private individuals are taken as productive assets; productive assets are to be held and managed by the government on behalf of the public. Productive assets chiefly consist of natural resources including land and water resources and other key means of production. ${ }^{96}$ Intangible things such as patents and copyright may also enter into the domain of productive assets. The nature and size of things falling into the domain of productive assets obviously depend on the stage of the economic development of the society which adopts this classification of things. $^{97}$

\footnotetext{
${ }^{93}$ See Kennethr R. Minogue, "The Concept of Property and Its Contemporary Significance” in the International Library of Essays in Law and Legal Theory, Property Law Vol. 1 at 15. Here the author distinguishes among personal attributes (e.g., quick wits), personal property (e.g., the clothes on our back) and productive property (e.g., farms and factories). Minogue thinks that all the three categories of property might be the source of immense influence on others.

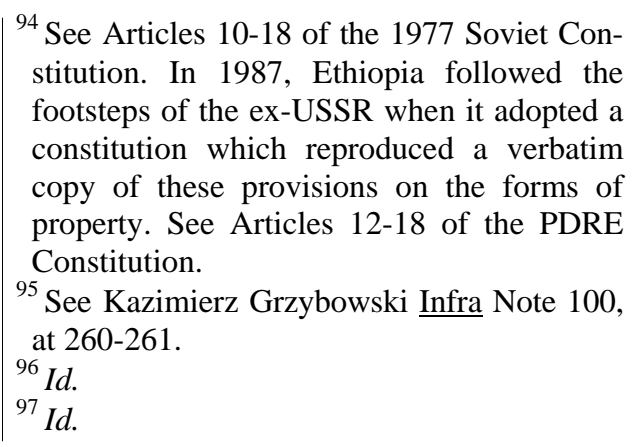

${ }^{94}$ See Articles $10-18$ of the 1977 Soviet Constitution. In 1987, Ethiopia followed the footsteps of the ex-USSR when it adopted a constitution which reproduced a verbatim copy of these provisions on the forms of property. See Articles 12-18 of the PDRE Constitution.

${ }^{95}$ See Kazimierz Grzybowski Infra Note 100, at $260-261$

${ }^{97} \mathrm{Id}$. 


\subsection{Reasons for the classification}

It is argued by the proponents of socialism that some of these assets are the products of nature and created by no one but by nature for every one. ${ }^{98}$ Some of these assets are produced by the capitalist class not as a result of its own innovative power but due to monopoly over state power and years of merciless exploitation of the working class. Thus, these resources shall be possessed by the state in the name of all its citizens. Citizens will have indirect benefit from some of these resources. In relation to others such as land, citizens will have individual access to the same and will enjoy proprietary rights over such resources but short of ownership. No single person, be it an individual or an association or even the government, shall have command in the sense of possessing ultimate say over these resources. ${ }^{99}$ Collective things are seen as a heritage of nature and past generations; to be used for the common good by the present generation and to be passed onto the future generation.

\subsection{Implications of the classification}

The classification of resources into personal and productive is featured uniquely by gradation in the protection of which the law offers to each of these classes. The property of the state as the foundation of the social and economic order calls for the highest degree of protection. For example, of the property in private (individual) ownership, only the property of working peasants and artisans enjoys the protection of the state. The motivation behind the varying degree of protection is to ensure that private property must not prejudice public interest.

Special protection of socialist property is primarily reflected in the fact that the law makes it impossible to transfer objects of socialist ownership into any other ownership. Transfer of property from one socialist ownership into any other has little legal significance as it always remains in state ownership and the socialist juristic persons "merely exercise the right of ownership vested in the state in their own name with regard to assets in their management."100

The state is the sole owner of all state property, regardless of what it is or who manages or uses it; state organizations exercise within the limits established by law only the right of possession, use, and disposal of state property attached to them in accordance with the aims of their property and the purpose of the property. State property is not subject to attachment by creditors; execution of creditors `claim may apply only to raw material, fuels and other

\footnotetext{
${ }^{98} I d$.

${ }^{99}$ Id.

${ }^{100}$ Kazimierz Grzybowski, Reform of Civil Law in Hungary, Poland and Soviet Union, 10 Am.J.Comp.L3 (1961) at 261-262.
} 
property included in the working capital of state organization. ${ }^{101}$ Nor is it open to prescription. A person may by taking possession thereof, acquire ownership of the usual objects of personal property in case they have no owner, and other things shall become the property of the state. ${ }^{102}$

Countries including Ethiopia that claimed to have adhered to Marxist doctrine in the past recognized the distinction between personal and productive assets. In those countries the use of the term 'private things' was deliberately avoided as that was said to carry with it the connotation of unbridled accumulation of private holdings. The provisions of the PDRE Constitution (1987) dealing with property were a verbatim copy of Articles 10-18 of the Soviet Constitution of 1977. These provisions of the PDRE Constitution merely restated the legislative pronouncements regarding forms of ownership the then government of Ethiopia had been issuing between 1974 and $1986 .{ }^{103}$ Articles 12-18 of the PDRE Constitution provided that:

The forms of ownership of the means of production are socialist, that is, state and cooperative ownership, private ownership and other forms of ownership as determined by law. State ownership is public ownership. The Ethiopian State shall, through the ownership of key production, distribution and service enterprises, play the leading role in the economy. Natural resources, in particular land, minerals, water and forest, are state property. Private ownership shall, guided by state policy, carry out activities beneficial to the national economy. The right to transfer private ownership in accordance with the law is guaranteed. Personal property is protected by law. The right to transfer personal property in accordance with the law is guaranteed. The state may, where public interest so requires, purchase, requisition [sic: expropriation for immovable] by making appropriate payment, or nationalize upon payment of compensation, any property in accordance with the law. Labor is an honorable source of wealth and well being of the society. The social standing of any person shall be determined by his work.

When read together with other proclamations regulating the ownership of the means of production, ${ }^{104}$ these constitutional prescriptions virtually abolished private ownership of property except in the trivialized sense of the term. ${ }^{105}$ As the above quotation indicates, a mechanism of constant nationalization

\footnotetext{
${ }^{101} I d$.

${ }^{102} \mathrm{Id}$.

${ }^{103}$ The term 'collective ownership' has not been consistently used in statutes in Ethiopia. Collective ownership, public ownership, government ownership and state ownership are terms used interchangeably.

104 See Public Ownership of Rural Lands Proc. No 31, 1975, Neg. Gaz. Year 34 No
}

26. See Also Government Ownership of Urban Lands and Extra Houses, Proc No 47, 1975, Neg. Gaz. Year 34, No 41.

${ }^{105}$ Farmers could have use right over a plot of land whose size was limited by legislation and practice, too. Urban dwellers could not own more than one dwelling house; when they elected to sell such house the state was privileged to have preemption right. (cont.) 
was built into these statutes to nib at its bud of any sign of increase in the size of personal assets.

\subsection{Distinctions}

A description of things analogous to, yet different from collective things is in order. Collectively owned things are different from common things though there are many similarities. Common things also called universal things (e.g. the sun, the moon, the atmospheric air and the high seas) cannot be owned by any entity even by the state in their entirety though that may be possible as a matter of theory. "Common things are those which do not belong to any body and which may be used by all, e.g., the air, the sea, the river water, the solar heat. They are so abundant, that every one may take of them what he needs without depriving any body else." ${ }^{\text {"106 }}$ These are resources dedicated to mankind in general whether such resources are traced to, as done by writers of religious inclination to the workmanship of God or taken as gift of nature as claimed by writers of secular orientation.

There are several common bonds between collective things and things in the public domain of the state. Both are controlled by the state indefinitely. Both are held and managed by the state in the name of the entire nation in order to avoid conflict of the wills of the multitude and unbearable transaction costs. The state shall deploy both to the betterment of its citizens. Citizens are entitled without distinction to benefit either directly or indirectly from such resources. Moreover, in both cases one is not expected to buy her way in for membership is open and free. Hence, the essential commonalities between collective assets and things in the public domain are understood if two questions are posed: who is entitled to have beneficial interests in such resources (all citizens) and in whom the power to make decisions regarding the same is vested (state authorities)?

Collective things are confused in some property law literature with things in the public domain. For example, a distinguished property treatise writer said:

...there is a common usage of collectively owned thing or there is a complete dedication of it to the general service, which in many cases can be had without

105 (cont.) Small businesses were allowed only in the course of so called transitional period and even in that case a capital ceiling was put in place. This approach was pretty much similar to the approach taken by the Soviet property law which abolished private property in principle and recognized small ownership in contrast with the Bulgarian property law approach which did permit private ownership in principle but prohibited large scale ownership. See N. Dolapchiev, Law and Human Rights in Bulgaria,29 International Affairs 1(1953) at 65 .

${ }^{106}$ Aubry and Rau, Droit Civil Francais, Vol. II, $7^{\text {th }}$ ed. (An English Translation by the Louisiana Law Institute), (St. Paul Minn West Publishing Co.) (1966). 
any contact with the thing used; it is thus the entire nation that derives an advantage from its battleships and its forts, although the citizens themselves, individually, make no use of them and are not in possession of them and many have not even seen them... ${ }^{107}$

Yet, the two classes of things are different in important respects. The above quotation may apply to things in the public domain of the state, but not necessarily to collectively owned resources for citizens may have the opportunity to have individual and direct enjoyment of collectively owned property. For example, in Ethiopia, both urban and rural lands are collectively owned but, for instance, plots are allotted to each farmer who has individual exclusive possession over such plot.

Secondly, one can imagine a thing in the public domain (e.g. a shield which can be taken as antique), which is in possession of a private person whose ownership right is limited by virtue of the character of the thing she owns. Technically speaking, heritages held by mosques and churches are within private domain as these institutions are not part of the state and are established and sustained by private initiatives. But, for all practical purposes, cultural heritages held by mosques and churches in Ethiopia are part of the public domain. In the case of collective assets, they are held by the state (or at least by association of persons mandated by the state) to manage a given resource to the common good.

Third, collective ownership is often, if not always, ideologically motivated. Collective assets, as history witnesses, usually result from nationalization. On the other hand, things in the public domain of the state do not necessarily have a bearing on assault against private possessions by way of nationalization. ${ }^{108}$ It is not possible or feasible or desirable to individualize and confer exclusive possession on individuals in respect of at least some of the things in the public domain. Yet, physical apportionment in order to bestow exclusive property rights on individuals in respect of a collective asset (e.g. land) may be seen as possible or feasible and even desirable, at least from the perspective of some people.

107 See Marcel Planoil, Supra Note 8 at 800 801. Another writer, M. Ducrocq made a similar confusion in writing:: "If the citizens were the owners of the national or communal property, they would be entitled to ask for its partition, for they would be the owners of undivided property and nobody can be forced to remain in in-division...the result would be the spoliation of future generation and the destruction of the domain of the state in favor of the generation of then living. If the citizens cannot sue for partition, it is not because the national property is owned by a fictitious person, who would be a fantastic person, but it is because there are two ways of being owner. And collective ownership lasts as long as its dedication to the collectivity does not entail partition.."

${ }^{108}$ See Marcel Planoil, Supra Note 8. 
Collectively owned things are not the same as jointly owned things which are in the state of in-division. Collective ownership suppresses the autonomy of individual shares; those shares do not exist in the sense that the individual, even if she is considered as an owner, cannot exercise the rights attached to ownership.

On the other hand, joint ownership permits the autonomy of the individual because individual property subsists in shares. In the case of joint ownership, each of the shares, even if it is physically merged into the others, has its special owner; undivided co-ownership is always individual ownership with physical merging of the shares. ${ }^{109}$ Collective ownership, on the other hand, rests upon the necessary grouping together of the person to which it belongs and such things are not intended to become the subject matter of private ownership. $^{110}$

\section{Ordinary movables and special movables}

Mere adherence to the major scheme of classification of goods in the Code, i.e., the law of movables and immovables, leaves many issues of acquisition and transfer of movables unanswered. The same procedure of transfer does not apply to all kinds of movables. And not all movables are subject to the law of possession in good faith. Thus, a distinction among movables is necessary to identify the proper rules of transfer and acquisition of ownership regarding movables.

Recognition of the division of movable things into ordinary and special can be inferred from Articles 1186/2, 2267/2 and 3047/2 of the Code. Special movables may be corporeal (e.g. motor vehicles) or incorporeal (e.g. business). ${ }^{111}$ The basis of this dichotomy of movable things into special and ordinary seems to hinge entirely on the wishes of the legislature. When the legislature deems it appropriate to single out a movable thing and put it in the category of special movable, that is all to it. Some movables are seen by the lawmaker as deserving special treatment because of a combination of many factors such as their economic value (e.g. aircrafts and ships ${ }^{112}$ ), security reasons (e.g. arms) and the need to ensure continued enjoyment by debtors after such things are given in the form of security (e.g. construction machinery).

\begin{tabular}{|c|c|}
\hline $\begin{array}{l}{ }^{109} \text { Id } \\
{ }^{110} \text { Id } \\
{ }^{111} \text { See Art. } 124 \text { of the Commercial Code } \\
\text { which treats business as a special movable. } \\
\text { There are other laws which give special } \\
\text { treatment to some movables. For e.g. TV } \\
\text { sets, motor vehicles, construction machinery }\end{array}$ & $\begin{array}{l}\text { and arms are considered by separate law as } \\
\text { special movables. } \\
112 \text { For the purposes of transfer, ships, vessels } \\
\text { and airplanes are assimilated to immovable } \\
\text { property in France and Louisiana. See A. N. } \\
\text { Yiannoplous, "Movables and Immovables in } \\
\text { Louisiana and Comparative Law," } 22 \text { L.L.R. } \\
\text { (1961-1962) at 561. }\end{array}$ \\
\hline
\end{tabular}


This section explains rules applicable to ordinary movables and special movables, distinguishes special movables from ordinary movables, and comments on rules applicable to motor vehicles and shares in business associations.

\subsection{Ordinary movables}

Every movable which has not been classified by the law as a special movable is an ordinary movable. Registration is unnecessary to effect transfer of ownership over ordinary movables. Moreover, there is no need to secure a title certificate in connection with ordinary movables. In order to transfer ownership over ordinary movables there is a need to have cause in the sense already mentioned, i.e., juridical act (contract or testament) or law (court order). In addition, there is a need to effect delivery of the ordinary movable from the transferor to the transferee. In French law, an intention to transfer ownership as expressed in a valid agreement without the need to effect delivery is good enough to transfer ownership over movables. ${ }^{113}$ In Germany, however, an intention to transfer ownership as indicated in an agreement followed by delivery leads to transfer of ownership in respect of movables. ${ }^{114}$

The Ethiopian law of ordinary movables has followed the German approach. Under Article 2274 of the Code, delivery involves the handing over of a thing and its accessories to the transferee. Article 2274 of the Code offers just one type and the most common sense of delivery. ${ }^{115}$ In respect of ordinary movables, delivery leads to possession, which in turn leads to the presump-

\footnotetext{
${ }^{113}$ K.W. Ryan, “An Introduction to The Civil Law”, (Australia, The Law Book Co. Of Australasia PTY LTD., 1962) at 170-171.

${ }^{114} \mathrm{Id}$.

115 Roman law gave recognition to various types of delivery. Constitutum possessorium refers to the case where a transferor in possession could agree to transfer ownership but to retain possession of the thing in some other capacity than that of owner. Traditio brevi manu occurs when a transferee was in possession of the thing, but not as owner, an agreement that she should become the owner would transfer the ownership to her. Traditio longa manu is the situation where the transferor could point out a thing to the transferee and authorize her to take such thing at her will; traditio per cartam, literally means agreements alone, the delivery of a written agreement instead of delivery of

the thing; here clauses would be inserted in the agreement under which the owner divested herself of ownership and retains possession as a mere detentor. The fifth form is agreement followed by actual handing over the subject matter to the transferee, i.e., actual delivery. In these five cases, Roman law put one common central condition, which is the transferor should intend to part with ownership and the transferee shall intend to obtain ownership. Under Roman property law, if a seller intends to sell a movable thing and the buyer intends it to be a gift, title may pass. On the other hand, if the seller intends loan while the buyer intends a gift or sale, there is no unity of mind and thus title would not pass. W.W. Buckland, "A Manual of Roman Private Law," 2ed. (1953) at 133-136. Some of these modes of delivery are incorporated in Arts 1144, 1145 and 1147 of the Code.
} 
tion of ownership. ${ }^{116}$ Simply stated, she who possesses an ordinary movable is assumed to hold it for herself and to be owner thereof. As ownership over ordinary corporeal movables may be transferred when possession is transferred, whosoever is in possession of an ordinary movable is presumed to possess it on her own behalf and to be the owner of such thing. ${ }^{117}$ If anybody disputes such ownership, the obligation to disprove such presumption is borne by the disputing party. ${ }^{118}$ For instance, a bare owner will surely rebut the presumption that a movable thing she has given in usufruct is owned by the usufructuary. A pledgor and an owner of a lost thing may set aside an inference of ownership in favor of a pledgee and a finder, respectively, arising out of their possession. ${ }^{119}$

The rule that a cause followed by delivery is sufficient to transfer ownership over ordinary movables is tied to one of the policies of property law. A transferee of an ordinary movable is not required to ascertain whether or not the person with whom she is dealing is an owner. To introduce registration or some other formalities in relation to ordinary movables is to impede the smooth flow of goods in commerce. With regard to ordinary movables, to require formality is to put a practically impossible bureaucracy in the way of exchange of goods given the multitude of such products and the speed with which they change hands. If the purchaser's title could be attacked at any time, she would be reluctant to enter into transaction relating to movables; this would, in turn, impede the speed and reliability of commercial transactions. To avoid such inconveniences, the law has greatly simplified the requirements of transfer of ordinary movables. Establish cause and receive delivery of an ordinary movable, you become the owner thereof has become the favored rule.

\subsection{Special Movables}

As highlighted earlier, a transfer of ownership in respect of special movables requires a cause $e^{120}$, i.e., a contract of sale or donation or a testament or a court order. The cause should be accompanied by registration and issuance of a certificate of title by a proper authority. Possession of a special movable alone does not make one an owner thereof. ${ }^{121}$ The distinction between special

${ }^{116}$ See Art. $1193 / 1$.

${ }^{117} \mathrm{Id}$.

${ }^{118} \mathrm{Id}$.

${ }^{119}$ See Article 1193/2.

${ }^{120}$ Notice that the term used by the Amharic version of Art. 1184 of the Code may be translated as "juridical act” while the Eng- lish version makes mention of one type of juridical act namely an agreement.

${ }^{121}$ See Ditu Tufa v. Jemal Shita (Sup. Ct., Civil File No 666/82, (Sene 1982 E.C).; Colonel Belayneh Mengistu v. Mugyb Seid, Sup. Ct., Civil File No 305/86, (Hidar 1987 E.C.); Hagbes PLC v. Colonel Mulugeta (Sup. Ct., 1986 E.C.) 
and ordinary movables has a clear legal basis. Article 1186/2 envisages the issuance of special laws that single out some movables and implies that special steps are envisaged in their transfer. ${ }^{122}$ Special movables are limited in number under Ethiopian property law. The list of such movables include; businesses, ${ }^{123}$ motor vehicles, ${ }^{124}$ construction machinery, ${ }^{125}$ ships $^{126}$, and non-negotiable instruments, ${ }^{127}$ patent ${ }^{128}$ and trademarks ${ }^{129}$. Considerations of security and safety (e.g., firearms), debt security (e.g. business chips and aircrafts), easier identification of the true owner for the purpose of liability (e.g., motor vehicles) are the major policy reasons for the designation of certain movables as special movables. However, the factor due to which a certain ordinary movable joins the category of special movables appears to be dictated by a variety of other interests.

When the law considers a certain movable as having special significance, it may designate it as a special movable. For the purpose of transfer, special movables are elevated to the status of immovable property. If, for example, Ato Kumsa owns an automobile which he sells to W/rt Semira, the latter is mere possessor of car (even after having paid the full price of the car) until Ato Kumsa surrenders the possession of the car to the buyer together with transfer of a certificate of title thereby enabling W/rt Semira to have a certificate of title in her own name.

\subsection{Special movables versus ordinary movables}

Unlike the case of ordinary movables, one cannot claim to be an owner of a special movable by mere possession. As a corollary, one cannot establish the ownership of a special movable by proving mere possession. Second, one cannot acquire the ownership of special movables through possession in good

\footnotetext{
122 See Article 2267.

123 See Art. 3047. See also Arts. 150-205 of the Commercial Code of Ethiopia.

${ }^{124}$ See Motor Vehicle and Trailer Regulation, Legal Notice, 1969, No 360, Year 28 No 9.

${ }^{125}$ See Registration and Control of Construction Machinery, Art. 4/1, 1999, No 177 Year 29 No 61.

${ }^{126}$ A ship must be registered. For the valid transfer of property rights in a ship with Ethiopian nationality the instrument which establishes such rights must be "drawn up in a recognized legal form” and registered with ship registers. Publication must take place as well in order to set up such agreements against third parties. See Maritime Code of the Empire of Ethiopia, Arts. 7-8, 45, and

50, Proc. No 164, 1960, Neg. Gaz. Year 19, Extraordinary Issue No 1.

${ }^{127}$ Art. 341 of the Commercial Code provides that the effective transfer of registered shares requires registration. See also Arts. $722 \& 723$ of the same Code.

${ }^{128}$ See Inventions, Minor Inventions and Industrial Designs, Arts. 14 \& 15, Proc. No 123, 1995, Nega. Gaz., No 25 Year 54.

${ }^{129}$ Court practice as well as the practices of the previous Ministry of Trade and Industry, and now that of the Ethiopian Intellectual Property Office depict that ownership of trademarks is established not by mere use in commerce of a distinctive sign but by registration. A draft trademark law in pipeline is in line with this practice.
} 
faith. The belief on the part of an acquirer in the fact that the person with whom she concludes a sale contract holds title or is legitimate person to make transfer is destroyed by publicity which raises a presumption of knowledge on the part of the buyer. It appears that Articles 1161-1167 of the Code should not be invoked with regard to special movables for publicity destroys any claim of good faith on the part of a third party. For the purpose of transfer of ownership, special movables, e.g., business, motor vehicles and construction machinery, are treated as immovable things; registration and issuance of title deeds in the name of the current owner are required. It naturally follows from this that special movables are to be subjected to mortgage while non-fungible ordinary movables are to be charged with pledge.

On the other hand, the law simplifies the transfer of ordinary movables. Unlike, special movables the conclusion of a contract or testament followed by delivery effects transfer of ownership in respect of ordinary movables. The law desires their speedier movement in the market. A prescription that undergoes longer steps in the process of transfer of ordinary movables would be impractical and unnecessary; and that would impede their flow in commerce given their volume, number and frequent exchange of hands in a market.

\subsection{Transfer of motor vehicles}

In Habteab Tekle v. Esayas Like and Bezabih Kelile, ${ }^{130}$ the issue was whether ownership relating to a certain vehicle was transferred to the appellant. The appellant argued that he is the owner of a car which he bought from the second respondent after having paid the full price, on the basis of a contract of sale made in writing and authenticated with the proper authority. The appellant, thus, claimed that the ownership of the car has been transferred to him even if the title certificate relating to the car was not issued in his own name. The appellant stated that transfer of ownership relating to the motor vehicle was not transferred to him owing to circumstances beyond his control, i.e. because the second respondent (the seller) did not pay customs duties.

The first respondent, on the other hand, argued that the car was attached to satisfy the debt owed to him by the second respondent, in whose name the car was registered. The High Court held that the car in dispute was owned by the second respondent. The basis for the holding of the court was that transfer of ownership of special movables was equivalent to that of immovable property, and that the person in whose name a special movable such as a car is

${ }^{130}$ Supreme Court, Civil File No. 570/80 (Sene 22, 1980 E.E.) See Getaneh Agonafer V. Fantu Gutema (High Ct., Civil File No 369/78 (Miazia, 1980 E.C.); Eteneh Tadele V. Berta Construction (High Ct., Civil File No 285/80 (Gnbot 1980E.C.). 
registered (and title certificate is issued) is the owner thereof. The High Court thus found that the title deed of the car in dispute bears the name of Bezabih Kelile (second respondent), thereby making him the owner of the car, and the Court decided that the car could be attached to satisfy the claim of the first respondent (Esayas Like).

However, the Supreme Court reversed this decision of the High Court. The Supreme Court invoked Articles 1186/2 and 1195 of the Code, and stated that he who possesses a title certificate pertaining to a special movable in his own name is presumed to be the owner. The Supreme Court stated that the presumption laid down under Article 1195 of the Code can be set aside by contrary evidence. According to the Supreme Court, the contrary evidence is one of the grounds embodied in Article 1196. The provision cited by the Court enables setting aside the presumption of ownership by virtue of title deed where it was not issued in accordance with the law or was issued by an authority having no jurisdiction; or where the title deed was issued on the basis of an invalid act; or if the person in whose name the title deed is issued acquired the ownership after the day on which the title deed was issued.

The Court noted that the appellant could have completed the process of transfer of ownership if the second respondent had paid the required customs duties. The second respondent did not pay the customs duties on the car, which he imported duty free and which upon transfer was required to be taxed. The Supreme Court further stated that the contract of sale of the car took place a year before the first respondent instituted debt recovery suit against the second respondent showing that the appellant had bought the car from the second respondent well before the attachment order. Based on these considerations, the Court reversed the decision of the High Court and ruled that the ownership of the car had to go to the appellant.

It is submitted that the decision of the Supreme Court is wrong because the appellant did not rebut the presumption that the car belonged to Bezabih Kelile within the meaning of Articles 1195 and 1196 of the Code because the title certificate bears his name. In the decision of the Supreme Court, none of the three factors envisaged to rebut the presumption of ownership under Article 1195 was shown to have existed. The Court considered the failure to pay tax by Bezabih Kelile as a good cause that had to go into the determination of rebuttal factors. Apparently, Bezabih's failure to pay tax has obstructed the completion of the transfer of the title deed of the car to Habteab's name. Nevertheless, that cannot be considered as one of the ingredients or constitutive elements of the provisions invoked by the Supreme Court which would warrant setting aside the presumption of ownership contested in the appeal 
under consideration. A judgment delivered in the absence of such rebuttal factors would contravene a straightforward legal rule; and obviously casts doubt on the predictability of court decisions.

On the top of that, the fact that the appellant bought the car in dispute from the second respondent well before the attachment order does not have any legal consequence as state of mind of an acquirer is not relevant in the case of special movables. The car in dispute was still owned by the second respondent in whose name it was registered with the pertinent authority. The Court should, however, be praised for recognizing that for the purpose of transfer, special movables are similar to immovable property and that the rules designed to regulate the latter may apply, with the necessary changes, to the transfer of the former.

Before winding up the discussion on the transfer of motor vehicles, it is worth making mention of the prevailing practice. As a matter of practice, a contract of sale of a motor vehicle is required to be made in writing and be authenticated by the proper authority. The seller (or her heirs) and the buyer have to appear in person or via their agents, before the authority in charge of registering motor vehicles, and request the cancellation of the name of the former and enter in the register of motor vehicles the name of the buyer.

The pertinent law, however, does not require written agreement, authentication and personal appearance ${ }^{131}$ of the seller and the buyer. As matter of law, in the case of conventional transfer of title in respect of a motor vehicle, the two parties fill out and sign a form annexed to the pertinent law called Title Transfer Page. The seller alone delivers the completed Title Transfer Page along with the Car Booklet Title bearing the name of the seller to the concerned authority. The concerned public authority verifies the signature of the

131 The requirement of personal appearance has on many occasions complicated title transfer process because sellers in some cases refuse to accompany the buyer. In that case, sellers ask the concerned authority to effect them the transfer but in vain. The buyer sues the seller requesting the court to compel him to appear in person before the proper authority to facilitate the transfer process. Some five years ago, this type of litigation generated a huge controversy between courts and practitioners. Some judges took the stance that the buyer had to request the authority in charge of registration of motor vehicles and should it

refuse to do so, she had to file a suit against the authority; the practitioners, on the other hand, insisted that the courts had to order the seller to personally appear before the authority to effect the transfer. Some courts however accepted plaintiffs plea and ordered defendants to make a personal appearance to speed up title transfer. See Shiferaw Tsegaye v. Wendemu Bekele (Sup. Ct., Civil File No 800/81 (Yekatit, 1981.); Lema Kebede v. Muluneh Becheri and Tadele Beyene (Sup. Ct., Civil File 185/89, Tahesasse 1991E.C.; Esmail Nur v. Fikremarkos Teklu (First Instance Ct., Civil File No 1000/89, Tahsas, 1991 E.C. 
seller; cancels the old title certificate and then issues a new title in favor of the buyer. $^{132}$

\subsection{Transfer of shares}

Special movables as already indicated can be either tangible or intangible. Shares are among the most important kinds of intangible special movables. Under the Commercial Code of Ethiopia, shares in a business association are divided into two on the basis of the steps followed in transferring them: bearer (ordinary) shares and special shares. The reading of the relevant provisions of the Commercial Code reveals the following. The transfer of ownership or interest in a bearer share which perhaps may be issued only by a share company ${ }^{133}$ is accomplished through two steps: cause which may be a juridical act or court order or the application of the rules of intestate succession plus delivery of the certificate representing the proprietary interest in the share. ${ }^{134}$ On the other hand, the transfer of special shares follows a different track. Even in the case of the transfer of ownership or interest in a special share issued by business associations in Ethiopia, cause is indispensable but something more is needed for the valid transfer of such interest to flow from a transferor to a transferee.

Some illustrations can be provided here. In the cases of ordinary partnership, a partner may transfer the ownership of her share or interest short of ownership such as usufruct. The third party cannot step into such partnership nor can she obtain interest in a share of a partner unless the transfer is approved by the other partners. ${ }^{135}$ If partners approve the transaction, the memorandum of association needs to be amended. And third parties are affected by the transfer of a share in an ordinary partnership only after the amendment is deposited with the proper authorities and is published. ${ }^{136}$ The issues of approval by the other partners, amendment to the memorandum of association and the publicity requirements via registration and publication do apply to cases of transfer of a share by a general partner. But in the case of general partnership, a partner may constitute an interest short of ownership over her share in favor of third party without the consent of the other partners. Such assignment of

\footnotetext{
132 See Art. 9/2, Supra, Note 124. Similar lines of cases arose in connection with transfer of immovable property and with similar court disagreements.

133 See Arts 274/1 and 510/3 of the Commercial Code which prohibit a joint venture and a private limited company from issuing securities. Though there are no explicit prohibitions in relation to an ordinary partnership, a general partnership and a limited partner-

ship, one can argue that the articles under consideration shall be extended to the same. ${ }^{134}$ See Art. 340 (1\&2) of the Code she who is possession of a certificate evidencing a bearer share is taken as the owner of the same and thus entitled to receive dividends, redemption and take part in general meetings.

135 See Art. 250 of the Commercial Code

${ }^{136}$ See Art. 224 of the Commercial Code
} 
"beneficial interest in a share" to a third party, to use the language of the Commercial Code, will not bind the partnership; nor does the third party get the status of a partner. ${ }^{137}$

In the contexts of joint venture, limited partnership and private limited company, with some variations, transfer of the share of a member of such associations can be validly transferred to a transferee with the approval of the other partners, which is the fundamental element for the valid transfer of a share to a third party. In the case of a joint venture, under Article 274/2 of the Commercial Code in the absence of a contrary contractual agreement or perhaps legal provision, ${ }^{138}$ a unanimous agreement of the partners is required for a valid assignment of a share probably to a third party. ${ }^{139}$ It is not clear whether this article refers to the assignment of the ownership of a share or an interest in a share less than ownership or both types of assignments. Under this article, amendment of the memorandum of association is necessary but the very nature of the partnership will be destroyed if the amendment is publicized via registration and publication of the same.

Under Article 302 of the Code, the requirement of approval is maintained in the case of assignment of a share in a limited partnership but it is made a bit lax. Here the requirement is the approval of the managers and the majority members of the limited partners. The consent of the general partners may be disregarded. The registration and publication formalities are maintained. ${ }^{140}$ Like the case of joint venture, it is not clear if Article 302 does apply to the transfer of ownership or interests less than ownership or both by a partner of a limited partnership. Nor is Article 302 clear if it is referring to assignment to a third party or between the partners though it seems to refer to the former. In respect of transfer of shares to a third party ${ }^{141}$ in a private limited company, the following steps are required: the transfer deal must be made in writing; ${ }^{142}$ shall be approved by the majority of the members representing at least a three-quarters ${ }^{143}$ of the capital, and the approval shall be entered in the share register to be maintained by the company and be registered in the com-

\footnotetext{
${ }^{137}$ See Art. 283 of the Commercial Code

138 The phrase "unless otherwise provided" under Art. 274/2 of the Commercial Code may refer both to a contrary provision and agreement

${ }^{139} \underline{\text { Id. }}$.

140 See Art. 224 of the Commercial Code

141 Assignment of share between members can take place without restriction absent a contrary provision in the article of associa-

tion of the company. See Art. 523/1 of the Commercial Code of Ethiopia

142 This means the contract must be signed by the parties and attested by two witnesses by virtue of Art. 1727 of the Code.

143 This requirement can be made more stringent by the articles of association, for example, which may set the vote of members representing more than $75 \%$ or even $100 \%$ share of the company. See Art. 523/2 of the Commercial Code.
} 
mercial register. ${ }^{144}$ If one or more of these conditions are missing, the transfer contract will not bind third parties, the company and perhaps even the transferor and the transferee. ${ }^{145}$ In case the share of a member of a private limited company is attached, the third person purchasing such share may step into the company upon the approval of the other members. ${ }^{146}$

In relation to transfer of registered shares in a share company, there appear to be two conditions that are stated in Articles 333 and 341 of the Commercial Code that are written in the spirit of free transfer of shares. These two requirements may be described as registration of the transferred share in the name of the transferee in the register of shareholders that shall be kept at the head office of the transferor's share company ${ }^{147}$ and compliance with any restrictions which may be specified in the articles of association or by resolution of an extra-ordinary meeting by virtue of Article 333 of the Commercial Code. Failure to observe any of the two conditions of transfer will make the transfer a mere attempt; the person trying to effect transfer remains a shareholder and the other person cannot enjoy the status of a shareholder. It is clear that Articles 333 and 341 of the Commercial Code do apply to the case of transfer of ownership either freely or for consideration and either before or after the death of the transferor; but it is not clear if these stipulations do apply to the case of the constitution of property interests (e.g. usufruct or pledge) which are less than transfer of full or partial joint ownership over the share of a shareholder. ${ }^{148}$

In respect of a cooperative society, transfer of a member's share either as a whole or a portion thereof or an interest in the share less than ownership such as pledge and usufruct can take place. ${ }^{149}$ No transfer by a member of her share or benefit in a cooperative society shall be valid unless: the member has held such share or benefit for at least one year before the transfer and the

\footnotetext{
${ }^{144}$ See Arts. 522 and 523 of the Code. See also Art. 524 of the same Code for the case of transfer of the share of a deceased member of a private limited company.

${ }^{145}$ Art. 522 of the Commercial Code appears to have this message. This provision may mean that, absent the formalities indicated therein, the agreement purporting to transfer share will have effect between the transferor and the transferee, but does not bind third parties and the company.

${ }^{146}$ See Art. 523/5 of the Commercial Code.

${ }^{147}$ See Art. 331 of the Commercial Code. An analogous register of shares shall also be maintained by any private limited company

under Art. 521 of the same Code.

${ }^{148}$ It seems that for the exercise of such subordinate rights established over a share to be effective, communication to the share company is necessary, which may be inferred from Art. 329 of the Commercial Code for one cannot vote at meetings as a beneficiary of usufruct over a share in a given share company without some kind of communication to such share company about the creation of such right.

${ }^{149}$ See Cooperative Societies Proclamation, Proc. 147, 1998, Art. 19, Fed.Neg.Gaz., Year $5^{\text {th }}$ No.27.
} 
transfer is approved by the management committee. ${ }^{150}$ On the death of a member of a primary society, her share or benefit shall be transferred to one of her heirs designated as such in the register of society or failing such designation to her legal heir at law, and where such heir is a member or is willing to be a member. Where such heir is not a member or she is a member but does not wish to become or is not admitted as a member, she shall be paid the value of the share or benefit of the deceased member. ${ }^{151}$ Where the heir accepts and is accepted as a member and if the shares or benefits to be transferred to such heir exceed ten percent of the total paid up capital of the society, the member shall be paid the difference in cash. ${ }^{152}$ The transfer or payment made to an heir shall not be reversed due to the claims made by third parties on the society.

In conclusion, the requirements for transfer of shares in the case of ordinary partnership, joint venture, general partnership and limited partnership are more stringent than the requirements needed to transfer share in a private limited company. Such conditions are relatively loose in relation to transfer of shares in a share company as marketability of shares is one of the hallmarks of share companies. This informs us whether the emphasis is on the name, image and character of the incoming member or merely on her capital contribution. With the exception of private limited companies and cooperative societies, the conditions under which an heir or a member may assume membership in other business associations are not outlined. If the memorandum or articles of associations of these business associations are silent, too, the private limited company provisions on this point should apply with the necessary changes.

With the exception of the case of private limited companies, another issue not regulated by the Commercial Code (including the cooperative law) is the question of transfer of shares or interest short of ownership in a share between members. This lacuna in the pertinent law should also be covered either by the bylaws or by analogy because such internal transfers might lead to undesirable concentration of decision-making power in the hands of one or few members of a business association. Aside from the cases of ordinary partnership, general partnership and cooperative societies, the conditions necessary for the establishment of rights short of transfer of title over a share are not provided for. It is argued here that in the case of absence of a stipulation in the memorandum or articles of association, the general partnership provisions on this point shall (with the necessary change) apply to the creation of rights less than transfer of ownership over shares issued by the other business organizations. Finally, it appears that the constitution of right of promise of

\begin{tabular}{l|l|l}
${ }^{150}$ Id., Art. 19/1 (a\& b). & ${ }^{151}$ Id., Art. 19/3 Id.
\end{tabular} 
sale $^{153}$ and preemption ${ }^{154}$ over a share in a business association shall be equated with transfer of shares and thus be regulated accordingly because such transactions may eventually lead to transfer of shares.

\section{Concluding remarks}

There are good reasons not to argue that the primary classification of things under the Code should be relegated to a secondary position. ${ }^{155}$ The argument implicitly advanced in this Commentary has been that the primary classification of goods under the Code is complemented by the various kinds of classification of goods embodied in various parts of Book III of the Code and other laws.

Limiting oneself solely to the analysis of the classification of things into movable and immovable things cannot help one to sufficiently understand the property law of Ethiopia. The taxonomy of corporeal versus incorporeal things can be employed to explain the object of property law of Ethiopia. Consumable things bear upon the law of usufruct and of loan; fungible things affect the law of possession, of accession and of contract. Indivisibility impacts the law of joint ownership and of matrimonial property. The law of movable things can be appreciated well if the class of ordinary and special movable is brought into the picture. The notion of personal property is of some relevance to identify resources, which are put beyond the domain of private ownership. And, the entire domain of state property is explained by the conception of private and public domain property.

In short, the subsidiary divisions are not meant to replace but to augment the dominant categorization of things by the Code, i.e., the law of movables and immovables. The student of Ethiopian property law should thus appreciate the role played by the multifarious kinds of subsidiary division of things spread over the various fields of private law of the country.

${ }^{153}$ See the words "a specific chattel” under Art. 1411/1.

${ }^{154} \mathrm{Id}$.

${ }^{155}$ It is submitted that the division of things into movable and immovable is and should be still alive in Ethiopia. If the classification of thing has to be organized around a key asset, Ethiopia at present does not have an asset more important than immovable property. Ethiopia is an agrarian society; immovable property still retains the center stage. The division of things into movable and immovable things is intelligible to layper- sons. Law is desired to be accessible, not only in terms of language but also in terms of idea. It is sensible to retain this division. In addition, the collectivization of land does not abolish the ownership of buildings. Further, people can still hold rights in land. A holder of land can enjoy usufruct, lease her land for a specific period of time, donate a portion of her land and mortgage lease right in the case of an investor. These rights are immovables by the object to which they apply as they are linked to an immovable asset. 